\title{
PPAR $a$ and PPAR $y$ Polymorphisms as risk factors for Dyslipidemia in a Chinese han population
}

\author{
Shu-Jun Gu,2, Zhi-Rong Guo ${ }^{2 *}$, Zheng-Yuan Zhou ${ }^{1}$, Xiao-Shu Hu${ }^{3}$ and Ming $\mathrm{Wu}^{4}$
}

\begin{abstract}
Background: The PPAR $a$ and PPAR $y$ are the key messengers responsible for the translation of nutritional stimuli into changes for the expression of genes, particularly genes involved in lipid metabolism. However, the associations between PPAR a / y polymorphisms and lipid serum levels in the general population were rarely studied, and the conclusions were conflicting. The objective was to investigate the associations of the PPAR a and PPAR $Y$ polymorphisms with dyslipidemia.

Methods: 820 subjects were randomly selected from the Prevention of Multiple Metabolic Disorders and MS in Jiangsu Province cohort populations. The logistic regression model was used to examine the association between these polymorphisms and dyslipidemia. SNPstats was used to explore the haplotype association analyses.

Results: In the codominant and log-additive models, rs1800206, rs1805192 and rs3856806 were all associated with dyslipidemia ( $P<0.005)$. When the most common haplotype L-G (established by rs1800206, rs4253778) was treated as the reference group, the $\mathrm{V}-\mathrm{G}$ haplotype was associated with dyslipidemia $(\mathrm{P}<0.001)$, higher TC and TG levels ( $P<0.01$ ). Moreover, when compared to Pro-C haplotype (established by rs1805192, rs3856806), the Pro-T, Ala-C, Ala-T haplotypes were associated with dyslipidemia $(p<0.001)$. A-T haplotype was associated with higher TC levels, $(p<0.01)$, and the P-T, A-C, A-T haplotypes were associated with higher TG levels $(p<0.01)$.
\end{abstract}

Conclusions: PPAR a and PPAR y polymorphisms and haplotypes may be the genetic risk factors for dyslipidemia.

Keywords: PPAR, Polymorphism, Dyslipidemia, Haplotype

\section{Background}

Cardiovascular disease (CVD)represents the leading cause of death in adults worldwide. Alterations in lipid and lipoprotein metabolisms have been investigated as important CVD risk factors [1]. It is well-known that high LDL-cholesterol (LDL-c) and triglycerides (TG) levels and low HDL-cholesterol (HDL-c) levels are strong predictable factors for cardiovascular events [2]. Epidemiological data have indicated a continuous increase in prevalence rate of dyslipidemia during the last decades [1]. The exact cause of dyslipidemia is not known. Genetics play an important role on lipid homeostasis. The peroxisome proliferator-activated receptor (PPAR) isotypesare ligand-activated nuclear transcription factors, which have been identified that they play a

\footnotetext{
*Correspondence: guozhirong28@163.com

2Department of Epidemiology, School of Public Health, Soochow University, Suzhou, Jiangsu 215123, China

Full list of author information is available at the end of the article
}

critical physiological role as lipid sensors and regulators of lipid metabolism [3,4]. The PPAR $\alpha$ and PPAR $\gamma$ were the key messengers responsible for the translation of nutritional stimuli into changes for the expression of genes, particularly genes involved in lipid metabolis [5]. PPAR $\alpha$ and PPAR $\gamma$ are encoded by distinct genes and have specific tissue distribution.

PPAR $\alpha$ is mainly expressed in tissues with extensive fatty acid catabolism and its activation leads to changes in the transcription of multiple genes that regulate lipid and lipoprotein metabolism including LPL, APOC3, APOA1 and APOA5 [6,7]. Common variants of the PPAR $\alpha$ have been described. Rs1800206 has been associated with variation in lipid serum levels in Caucasian and Indian populations [8,9]. Another polymorphism, rs4253778 has also been found that it is associated with variation in lipid serum levels [10]. But Mazzotti et al. found that there were divergences on the association 
results regarding both polymorphisms between their two studied population (São Paulo City and Cuiaba City) $[11,12]$.

PPAR $\gamma$ is highly expressed in adipose tissue, where it plays an indispensable role in the regulation of adipocyte differentiation, lipid storage, glucose metabolism and the transcriptional regulation of a number of genes involved in these metabolic processes. Some of the key target genes of PPAR $\gamma$ include the fat-specific ap2 gene, LPL, fatty acid transport, fatty acid binding protein, ABC-A1 $[4,13]$. The most studied of PPAR $\gamma$ polymorphisms is rs1805192 [14]. Rs3856806 variant has been found to be associated with traits, which modulate the associations observed with the rs1805192 [15]. At present, many studies have reported that rs1805192 and rs3856806 polymorphisms were associated with obesity, insulin sensitivity and Type 2 diabetes [16-18]. However, the associations between rs1805192 or rs3856806 polymorphisms and lipid serum levels in the general population were rarely studied, and the conclusions were conflicting.

In the previous study, we have found that PPAR $\alpha / \gamma$ polymorphisms (rs1800206, rs3856806 and rs1805192) were significantly associated with hypertriglyceridemia [19]. Thus, the purpose of this study was to further investigate the association of the four variants at the PPAR $\alpha$ (rs1800206, rs4253778 polymorphisms) and PPAR $\gamma$ (rs3856806 and rs1805192 polymorphisms) locus with dyslipidemia. This study is the first to investigate the role of PPAR $\alpha$ and PPAR $\gamma$ polymorphisms with dyslipidemia in Chinese Han population. Moreover, this is the first study that associated haplotypes of rs3856806 and rs1805192 polymorphisms with dyslipidemia.

\section{Results}

Table 1 describes the characteristics of the studied population. Dyslipidemia participants exhibited a significantly higher mean age, BMI and WC than non-dyslipidemia population. The four SNPs were within Hardy-Weinberg equilibrium $(\mathrm{P}>0.05)$. Linkage analysis showed there was no significant linkage disequilibrium between rs1800206 and rs4253778 or between rs1805192 and rs3856806 polymorphisms ( $\left.\mathrm{D}^{\prime}<0.75\right)$.

We further examined the potential associations between dyslipidemia and individual polymorphisms in PPAR $\alpha$ and PPAR $\gamma$ based on two models (codominant and log-additive models; Table 2). In the codominant model, when the LL genotype of rs1800206 was used as the reference group, the LV genotype appeared to have a higher risk for dyslipidemia (the adjusted OR 5.75, 95\% CI 3.91-8.46), whereas no association was observed to the VV genotype (adjusted OR 2.38; 95\% CI 0.43-13.31). In the log-additive model, rs1800206 also appeared to be associated with dyslipidemia, the adjusted OR (95\% CI) was 4.74(3.29-6.84). For the rs4253778 polymorphism, when the CC genotype was used as the reference group, the CG and GG genotypes were not associated with dyslipidemia (adjusted OR 0.95, 95\% CI 0.63-1.43; adjusted OR0.65, 95\% CI 0.24-1.78, respectively). Similar result was observed in the log-additive model(adjusted OR0.89, 95\% CI 0.64-1.23). For the rs3856806 polymorphism, when the $\mathrm{CC}$ genotype was used as the reference group, the CT and TT genotypes were associated with dyslipidemia (adjusted OR 1.58, 95\% CI 1.09-2.27; adjusted OR $2.23,95 \%$ CI 1.28-3.90, respectively). In the log-additive model, rs3856806 also appeared to be associated with dyslipidemia (adjusted OR 1.53; 95\% CI 1.19-1.97). For the rs1805192 polymorphism, when the ProPro genotype was used as the reference group, the ProAla and AlaAla genotypes were associated with dyslipidemia (adjusted OR 1.77, 95\% CI 1.22-2.56; adjusted OR 2.96, 95\% CI $1.70-5.14$, respectively). Similar result was observed in the log-additive model (adjusted OR 1.76, 95\% CI 1.36-2.27).

Haplotype association analysis showed the associations between V/G haplotype and dyslipidemia (OR = 5.20; 95\% $\mathrm{CI}=3.46 \sim 7.82 ; \mathrm{p}<0.001 ;$ Table 3 ) and between $\mathrm{V} / \mathrm{G}$ haplotype and TC and TG levels when compared to L/G haplotype (Difference $=0.4,95 \% \mathrm{CI}=0.22 \sim 0.59, \mathrm{p}<0.01$; Difference $=1.63,95 \% \mathrm{CI}=1.31 \sim 1.95, \mathrm{p}<0.01$, respectively; Table 2). In addition, when the most common haplotype $\mathrm{P}-\mathrm{C}$ was treated as the reference group, the P-T, A-C,

Table 1 Baseline characteristics of the studied samples

\begin{tabular}{|c|c|c|c|c|c|}
\hline Variables & Non- dyslipidemia $(\mathrm{N}=628)$ & Dyslipidemia $(\mathrm{N}=192)$ & Total $(N=820)$ & Statistical test values & p-Value \\
\hline Age $(\text { year })^{a}$ & $50.47 \pm 9.51$ & $48.65 \pm 8.97$ & $50.05 \pm 9.40$ & 2.354 & 0.019 \\
\hline Male $^{b}$ & $204(32.5)$ & $66(34.4)$ & $270(32.9)$ & 0.238 & 0.626 \\
\hline Smoke N (\%) & $160(25.5)$ & $45(23.4)$ & $199(24.3)$ & 0.326 & 0.568 \\
\hline Alcohol N $(\%)^{\mathrm{b}}$ & $129(20.5)$ & $43(22.4)$ & $205(25.0)$ & 0.305 & 0.581 \\
\hline BMI $\left(\mathrm{kg} / \mathrm{m}^{2}\right)^{\mathrm{a}}$ & $22.71 \pm 3.14$ & $23.77 \pm 2.95$ & $22.83 \pm 3.12$ & -4.130 & $<0.001$ \\
\hline$W C(\mathrm{~cm})^{\mathrm{a}}$ & $76.44 \pm 8.67$ & $81.50 \pm 9.21$ & $77.00 \pm 9.05$ & -6.978 & $<0.001$ \\
\hline
\end{tabular}

Note: means \pm standard deviation for age, BMI, WC; BMI: body mass index; WC: waist circumference. ${ }^{\mathrm{a}}$ Student's t-test; ${ }^{\mathrm{b}}$ chi-square test. 
Table 2 The association analysis between SNPs in PPAR- $\alpha / \gamma$ and dyslipidemia

\begin{tabular}{|c|c|c|c|c|c|c|}
\hline SNP & Model & Genotype & $\begin{array}{l}\text { Non- dyslipidemia } \\
(\mathrm{N}=628)\end{array}$ & $\begin{array}{l}\text { Dyslipidemia } \\
(\mathrm{N}=192)\end{array}$ & OR $(95 \% \mathrm{Cl})$ & $\mathbf{P}$ \\
\hline \multicolumn{7}{|c|}{ rs1800206 } \\
\hline & Codominant & $\mathrm{LL}$ & 524 & 98 & 1.0 & $<0.001$ \\
\hline & & LV & 99 & 92 & $5.75(3.91-8.46)$ & \\
\hline & & W & 5 & 2 & $2.38(0.43-13.31)$ & \\
\hline & Log additive & - & - & - & 4.74 (3.29-6.84) & $<0.001$ \\
\hline \multicolumn{7}{|c|}{ rs4253778 } \\
\hline & Codominant & CC & 469 & 146 & 1.0 & 0.670 \\
\hline & & CG & 133 & 41 & $0.95(0.63-1.43)$ & \\
\hline & & GG & 26 & 5 & $0.65(0.24-1.78)$ & \\
\hline & Log additive & - & - & - & $0.89(0.64-1.23)$ & 0.470 \\
\hline \multicolumn{7}{|c|}{ rs3856806 } \\
\hline & Codominant & CC & 343 & 75 & 1.0 & 0.005 \\
\hline & & CT & 237 & 89 & $1.58(1.09-2.27)$ & \\
\hline & & $\pi$ & 48 & 28 & $2.23(1.28-3.90)$ & \\
\hline & Log additive & - & - & - & 1.53 (1.19-1.97) & $<0.001$ \\
\hline \multicolumn{7}{|c|}{ rs1805192 } \\
\hline & Codominant & ProPro & 380 & 79 & 1.0 & $<0.001$ \\
\hline & & ProAla & 206 & 82 & $1.77(1.22-2.56)$ & \\
\hline & & AlaAla & 42 & 31 & $2.96(1.70-5.14)$ & \\
\hline & Log additive & - & - & - & $1.76(1.36-2.27)$ & $<0.001$ \\
\hline
\end{tabular}

Adjusted for gender, age, smoke, alcohol, body mass index and waist circumference.

A-T haplotypes were associated with dyslipidemia $(\mathrm{OR}=$ 1.90, $95 \% \mathrm{CI}=1.33 \sim 2.71, \mathrm{p}<0.001$; OR $=2.17,95 \% \mathrm{CI}=$ $1.53 \sim 3.09, \mathrm{p}<0.001 ; \mathrm{OR}=2.06,95 \% \mathrm{CI}=1.36 \sim 3.12, \mathrm{p}<$ 0.001 , respectively; Table 4). A-T haplotype was associated with TC levels, (Difference $=0.29,95 \% \mathrm{CI}=0.09-0.48$, $\mathrm{p}<0.01$ ), and the P-T, A-C, A-T haplotypes were associated with TG levels (Difference $=0.60,95 \% \mathrm{CI}=0.32$ $0.88, \mathrm{p}<0.01$; Difference $=0.87,95 \% \mathrm{CI}=0.58-1.17$, $\mathrm{p}<0.01$; Difference $=0.94,95 \% \mathrm{CI}=0.57-1.30, \mathrm{p}<0.01$, respectively).

Table 3 Haplotypes of PPARa rs1800206 and rs4253778 polymorphisms and association with dyslipidemia, TC and TG levels

\begin{tabular}{|c|c|c|c|c|c|}
\hline & rs1800206 & rs4253778 & Frequency & OR(95Cl\%) & P-value \\
\hline \multirow[t]{5}{*}{ Dyslipidemia } & $L$ & $G$ & 0.7477 & 1 & - \\
\hline & L & C & 0.1273 & $1.01(0.67 \sim 1.54)$ & 0.94 \\
\hline & V & G & 0.1084 & $5.20(3.46 \sim 7.82)$ & $<0.001$ \\
\hline & V & C & 0.0166 & $2.31(0.64 \sim 8.32)$ & 0.20 \\
\hline & rs1800206 & rs4253778 & Frequency & Difference $(95 \mathrm{Cl} \%)$ & P-value \\
\hline \multirow[t]{5}{*}{ Total cholesterol } & L & G & 0.7487 & 0 & - \\
\hline & L & C & 0.1263 & $-0.1(-0.26 \sim 0.05)$ & 0.2 \\
\hline & V & G & 0.1074 & $0.4(0.22 \sim 0.59)$ & $<0.001$ \\
\hline & V & C & 0.0176 & $0.1(-0.35 \sim 0.55)$ & 0.65 \\
\hline & rs1800206 & rs4253778 & Frequency & Difference $(95 \mathrm{Cl} \%)$ & P-value \\
\hline \multirow[t]{4}{*}{ Triglyceride } & L & G & 0.7476 & 0 & - \\
\hline & L & C & 0.1274 & $0.11(-0.17 \sim 0.38)$ & 0.45 \\
\hline & V & G & 0.1085 & $1.63(1.31 \sim 1.95)$ & $<0.001$ \\
\hline & V & C & 0.0165 & $0.43(-0.58 \sim 1.44)$ & 0.4 \\
\hline
\end{tabular}


Table 4 Haplotypes of PPARy rs 1805192 and rs3856806 polymorphisms and association withdyslipidemia, TC and TG levels

\begin{tabular}{|c|c|c|c|c|c|}
\hline & rs1805192 & rs3856806 & Frequency & Difference (95Cl\%) & P-value \\
\hline \multirow[t]{5}{*}{ Dyslipidemia } & Pro & $C$ & 0.5393 & 1 & - \\
\hline & Pro & $\mathrm{T}$ & 0.196 & $1.90(1.33 \sim 2.71)$ & $<0.001$ \\
\hline & Ala & C & 0.1692 & $2.17(1.53 \sim 3.09)$ & $<0.001$ \\
\hline & Ala & $\mathrm{T}$ & 0.0954 & $2.06(1.36 \sim 3.12)$ & $<0.001$ \\
\hline & rs1805192 & rs3856806 & Frequency & Difference (95Cl\%) & P-value \\
\hline \multirow[t]{5}{*}{ Total cholesterol } & Pro & C & 0.5395 & 0 & - \\
\hline & Pro & $\mathrm{T}$ & 0.1959 & $0.15(0.00 \sim 0.30)$ & 0.06 \\
\hline & Ala & C & 0.1691 & $0.09(-0.07 \sim 0.25)$ & 0.29 \\
\hline & Ala & $\mathrm{T}$ & 0.0956 & $0.29(0.09 \sim 0.48)$ & $<0.001$ \\
\hline & rs1805192 & rs3856806 & Frequency & Difference (95Cl\%) & P-value \\
\hline \multirow[t]{4}{*}{ Triglyceride } & Pro & C & 0.539 & 0 & - \\
\hline & Pro & $\mathrm{T}$ & 0.1963 & $0.6(0.32 \sim 0.88)$ & $<0.001$ \\
\hline & Ala & C & 0.1695 & $0.87(0.58 \sim 1.17)$ & $<0.001$ \\
\hline & Ala & $\mathrm{T}$ & 0.0951 & $0.94(0.57 \sim 1.3)$ & $<0.001$ \\
\hline
\end{tabular}

Adjusted for gender, age, smoking, alcohol consumption, BMI and waist circumference.

\section{Discussion}

In this study, we aimed to investigate the association of the four variants at the PPAR $\alpha$ (rs1800206, rs4253778 polymorphisms) and PPAR $\gamma$ (rs3856806 and rs1805192 polymorphisms) locus with dyslipidemia.

In the single SNP association analysis, we found that rs1800206 polymorphism was associated with dyslipidemia both in the codominant and log-additive models $(\mathrm{p}<0.001$, Table 2). Rs1800206 polymorphisms has been associated with changes in TG, total cholesterol, LDL- c, HDL- $c$ and APOA1 plasmacon centrations in many populations such as Caucasian, Indian and AfricanAmericans populations $[6,7,20,21]$, in part corroborating our findings. Some previous studies found that the $\mathrm{C}$ allele of rs4253778 was associated with increased total and LDL-c, atherosclerosis progression and increased risk for nonfatal myocardial infarction [10,22,23]. Although it seems that the rs4253778 polymorphism has its influence on metabolism disturbances, we did not find associations with dyslipidemia. Interestingly, Mazzotti et al. found divergences on the association results regarding the two polymorphisms between their two studied population (São Paulo City andCuiaba City) [11,12]. For instance, while $\mathrm{C}$ allele of rs4253778 was associated with higher HDL-c and lower TG and VLDL levels in the São Paulo population, the same allele was associated with dyslipidemia in the Cuiaba population. Mazzotti et al. [11] considered that the controversy might be explained by the differential population stratification within the two studied samples. These both admixed populations presented different proportions of participants with European and African ancestry, which may account for the differences found between the studies. Moreover, lifestyle and dietary habits differ substantially between these populations. So we thought the divergence on the association result regarding the rs4253778 polymorphisms between our study and other studies might be caused by the same reasons.

Haplotype association analysis showed the associations between V/G haplotype and dyslipidemia ( $\mathrm{p}<0.001$, Table 3) and between V/G haplotype and TC and TG levels ( $\mathrm{p}<0.01$,Table 3 ) when compared to $\mathrm{L} / \mathrm{G}$ haplotype (established by rs1800206 and rs4253778). These results confirmed the associations found when individual polymorphisms were analyzed. There is only one study that associated haplotypes of these two polymorphisms with lipid metabolism alterations. Mazzotti et al. [11] found that in the São Paulo population, carriers of the $\mathrm{L} / \mathrm{C}$ haplotype were at increased risk for dyslipidemia when compared to carriers of the most common $\mathrm{L} / \mathrm{G}$ haplotype $(p=0.021)$. In addition, carriers of the $\mathrm{V} / \mathrm{C}$ haplotype showed a tendency for increased risk for dyslipidemia, but it was not significant $(\mathrm{p}=0.055)$. Unfortunately, the definition for dyslipidemia in the São Paulo population is different from ours. So the associated haplotypes of these two polymorphisms with lipid metabolism alterations should be thoroughly investigated in future studies.

At present, many studies have reported that rs1805192 and rs3856806 polymorphisms were associated with obesity, insulin sensitivity and Type 2 diabetes [16-18]. However, the associations between rs1805192 or rs3856806 polymorphisms and lipid serum levels in the general population were rarely studied. Rs1805192 has been shown to be associated with lower levels of serum total and non-HDL in a Japanese population [24], lower LDL in T2D patients [25], 
or higher levels of serum HDL-cholesterol in family-based studies [26]. In obesity individuals, this variant was associated with a trend of an increase in TG and significantly associated with the presence of combined hyperlipidaemia [27]. In a group of 57 extremely obese men, this variant was related with an increase in TG. In CAD patients, Zhou et al. [28] found that rs3856806 polymorphism was associated with a higher HDL cholesterol level and a lower blood glucose level. Yilmaz-Aydogan [29] found that subjects with the CT heterozygote genotype of the rs3856806 polymorphism showed a higher serum triglyceride and VLDL-C concentrations than those with the CC homozgotes in the CHD patients with diabetes. Our study found that rs1805192 and rs3856806 polymorphisms were associated with dyslipidemia both in the codominant and log-additive models ( $p<0.01$; Table 2 ), suggesting an independent association between the two polymorphisms and dyslipidemia.

Haplotype analysis regarding rs1805192 and rs3856806 polymorphisms has also shown the associations with dyslipidemia, TC and TG levels. When compared to carriers of the most common Pro/C haplotype, the Pro- $\mathrm{T}$, Ala-C, Ala-T haplotypes were associated with dyslipidemia ( $\mathrm{p}<0.001$, Table 4$)$. In addition, Ala-T haplotype was associated with higher TC levels, $(\mathrm{p}<0.01)$, and the Pro-T, Ala-C, Ala-T haplotypes were associated with higher TG levels $(\mathrm{p}<0.01)$. So far, the haplotype analysis regarding rs1805192 and rs3856806 polymorphisms for dyslipidemia has not been reported yet.

Our study found that PPAR $\alpha$ and PPAR $\gamma$ haplotypes were associated with dyslipidemia. PPAR $\alpha$ controls the expression of a wide range of hepatic genes encoding for proteins involved in fatty acid catabolism and lipoprotein metabolism. Its activation leads to changes in the transcription of multiple genes that regulate lipid and lipoprotein metabolism including LPL, APOC3, APOA1 and APOA5. Vohl [9] and Sapone [30] et al. found that rs1800206 had functional consequences on receptor activity. PPAR $\gamma$ plays an indispensible role in the regulation of adipocyte differentiation, lipid storage, glucose metabolism and the transcriptional regulation of a number of genes involved in these metabolic processes. The key target genes of PPAR $\gamma$ include the fat-specific ap2 gene, LPL, fatty acid transport, fatty acidbinding protein, ABC-A1 and so on [6]. Deeb [31] found that the Ala allele of rs1805192 showed decreased binding affinity to the cognate promoter element and reduced ability to transactivate responsive promoters. rs3856806 was found to modulate the associations observed with the codon 12 substitution [15]. We thought rs1800206, rs1805192 and rs3856806 polymorphisms may influence the receptor activity, the ability to transactivate responsive promoters and so on to regulate the key target genes of PPAR $\alpha / \gamma$ which could influnce the lipid metabolism. But the specific biological mechanism needs to be further studied.

One limitation of this study is that these findings may not be generalizable to other populations. Large ethnically matched studies would be necessary to know if such reports are found in non-Chinese Han subjects. Second, the information on some lifestyle and dietary habits which might interact with PPAR $\alpha / \gamma$ genotypes or act as potential confounding factors was not available in our study.

In conclusion, our study has tested the association between four common polymorphisms within PPAR $\alpha / \gamma$ gene and dyslipidemia based on single-locus and haplotype analyses. These results may help to evaluate their polymorphisms and haplotypes as being characterized as genetic risk factors for dyslipidemia. Independent replications in large sample sizes are needed to confirm the role of the polymorphisms and haplotypes found in this study and the risk factors such as the lifestyle and dietary habits should be thoroughly investigated in future studies.

\section{Materials and methods Studied population}

Participants were recruited from the Prevention of MetS and Multi-metabolic Disorders in Jiangsu Province of China Study [32], which was initiated from April of 1999 to June of 2004. Totaled 4,582 subjects for whom five year follow-up data were obtained between March of 2006 and October of 2007. A total of 4,083 participants (89.11\%) received follow-up examination (the patients who attended the follow-up examinations were similar to those lost from the follow-up cohort in terms of age, sex, smoking status, alcohol intake, family disease history and metabolic variables; $p>0.05)$. After excluding subjects who had experienced stroke or exhibited cardiovascular disease ( $\mathrm{n}=36,11$ of whom died), type 2 diabetes ( $n=289,31$ of whom died), missing data $(n=133)$ or body mass index $(\mathrm{BMI})<18.5 \mathrm{~kg} / \mathrm{m}^{2}(\mathrm{n}=27,2$ of whom died), a total of 820 unrelated individual subjects (270 males, 550 females) were was selected from the remaining 3,731 cases by using simple random sampling and no individual was related. Subjects who were selected were similar to those who were not selected in terms of age, sex, smoking, alcohol, family disease history and metabolic variable. Blood samples of the 820 subjects were collected as a baseline and subjected to genotype analyses. Lipids measured at follow-up were used to examine the association with PPAR $\gamma$ polymorphisms in the study. All the participants signed the informed consent form. The study was approved by the ethic committee of Soochow University.

\section{Body measurements and laboratory methods}

Participants in baseline and follow-up study surveys both filled in a standard questionnaire and physical 
measurements and were collected blood samples in the morning after at least 8 hours of fasting (used to detect and establish cell library). The methods of investigation at the follow up were same as those at baseline. Cigarette smokers were those who reported smoking cigarettes at least once a day for 1 year or more. Total alcohol intake was expressed as the sum of milliliters of alcohol per week from wine, beer and spirits. The anthropometric measurements included body weight and waist circumferences (WC). BMI was calculated according to the Quetelet equation. Plasma glucose was measured using the oxidase enzymatic method. Serum total cholesterol (TC), HDL-c, and TG levels were measured by enzymatically. LDL-c concen-trations were calculated by using the Friedewald formula. The measurements were conducted using an automatic biochemistry analyzer (Hitachi Inc, Tokyo Japan). All analyses were performed by the same lab. The methods of investigation at the follow up were same as those at baseline.

\section{Genotyping}

Genomic DNA from participants was extracted from EDTA-treated whole blood, using the DNA Blood Mini Kit (Qiagen, Hilden, Germany) according to the manufacturer's instructions. The qualities of isolated genomic DNAs were checked using agarose gel electrophoresis and the quantities determined using spectrophotometry. Two approaches were employed to separate wildtype and mutated alleles for the four SNPs. rs4253778 was detected by plymerase chain reaction restriction fragment length polymorphisms (PCR-RFLP), and the left three SNPs were detected by Taqman fluorescence probe. Restriction enzyme was used to identify and cut specific sequence, then PCR was performed with the following primers: forward 5' - ACA ATC ACT CCT TAA ATA TGG TGG-3' and reverse 5' - AAG TAG GGA CAG ACA GGA CCA GTA -3'. A $25 \mu$ l reaction mixture was amplified by PCR, including DNA $20 \mathrm{ng}$, $0.05 \mu \mathrm{l}$ Ex Taq DNA polymerase, $1 \mu \mathrm{l} 10 \times$ buffer, $0.8 \mu \mathrm{l}$ dTNP, $0.1 \mu$ l Forward primers, $0.1 \mu$ l reverse primers. PCR conditions were as follows: initial denaturation for $3 \mathrm{~min}$ and $95^{\circ} \mathrm{C}$, denaturation for $10 \mathrm{~s}$ and $95^{\circ} \mathrm{C}$, annealing for $30 \mathrm{~s}$ and $63^{\circ} \mathrm{C}$, extension for $30 \mathrm{~s}$ and $72^{\circ} \mathrm{C}, 40$ cycles. ABI Prism7000 software and allelic discrimination procedure was used for genotyping of fore-mentioned four SNPs. A $25 \mu \mathrm{l}$ reaction mixture including 1.25ul SNP Genotyping Assays(20×), $12.5 \mu$ l Genotying Master Mix(2×), $20 \mathrm{ng}$ DNA, and the conditions were as follows: initial denaturation for $10 \mathrm{~min}$ and $95^{\circ} \mathrm{C}$, denaturation for $15 \mathrm{~s}$ and $92^{\circ} \mathrm{C}$, annealing and extension for $90 \mathrm{~s}$ and $60^{\circ} \mathrm{C}, 50$ cycles. Table 5 provides detailed information on the selected SNPs, including their features, allelic variants, and the minor allele frequencies.

\section{Definitions}

The criteria for lipid and lipoprotein levels were according to the National Cholesterol Education Program [33]. Participants were diagnosed with dyslipidemia if they had one or more of the following criteria: a plasma concentration of $\mathrm{TC}$ of $\geq 6.24 \mathrm{mmol} / \mathrm{L}$, plasma concentration of $\mathrm{TG} \geq 2.26 \mathrm{mmol} / \mathrm{L}$; plasma concentration of HDL-c of $<1.04 \mathrm{mmol} / \mathrm{L}$ for men or $<1.30 \mathrm{mmol} / \mathrm{L}$ for women; and a plasma concentration of LDL-c $\geq 4.14 \mathrm{mmol} / \mathrm{L}$.

\section{Statistical analyses}

The mean and standard deviation (SD) for continuous variables normally distributed and percentage for categorical variable were calculated. Median and interquartile range were calculated for continuous variables that were not normally distributed. Continuous variables were tested using the t-test and no-parametric test. Frequencies of categorical variables were tested using the chi-square test. Allele and genotype frequencies were calculated for each polymorphism and the $\mathrm{x}$ 2test was used to investigate deviation from Hardy -Weinberg equilibrium. The logistic regression model was used to examine the association between PPAR $\alpha / \gamma$ polymorphisms and dyslipidemia. Odds-ratio (OR) and 95\% confidence interval $(95 \% \mathrm{CI})$ were also calculated. Individual polymorphism data analyses were performed using SPSS 16.0. Estimation of linkage disequilibrium between polymorphisms was performed using SHEsis (http://analysis2.bio-x.cn/SHEsisMain.htm) software. Haplotype

Table 5 Description for 4 SNPs of PPAR- $a / \gamma$

\begin{tabular}{|c|c|c|c|c|c|}
\hline SNP ID & Chromosome & Position & Exon/Intron & Substitution & $\mathrm{MAF}^{\mathrm{a}}$ \\
\hline \multicolumn{6}{|l|}{ PPAR a } \\
\hline rs4253778 & 22 & 26021203 & Intron_7 & $G>C$ & 0.22 \\
\hline rs1800206 & 22 & 26004843 & Exon_5 & $L>V$ & 0.13 \\
\hline \multicolumn{6}{|l|}{ PPAR $Y$} \\
\hline rs1805192 & 3 & 12361238 & Exon_B & Pro $>$ Ala & 0.26 \\
\hline rs3856806 & 3 & 12415557 & Exon-6 & $C>T$ & 0.15 \\
\hline
\end{tabular}

${ }^{\mathrm{a}} \mathrm{MAF}$ in the total group of this study.

MAF, minor allele frequency; SNP, single nucleotide polymorphism. 
association analysis was performed using SNPStats web tool.

\section{Abbreviations}

CVD: Cardiovascular disease; LDL-C: LDL-cholesterol; TG: Triglycerides; HDL-C: HDL-cholesterol; PPAR: Peroxisome proliferator-activated receptor; BMI: Body mass index; WC: Waist circumferences; TC: Total cholesterol; PCR-RFLP: Plymerase chain reaction restriction fragment length polymorphisms; SD: Standard deviation; OR: Odds-ratio; Cl: Confidence interval.

\section{Competing interests}

The authors declare no conflicts of interests.

\section{Authors' contributions}

ZRG, XSH and ZYZ designed research; ZYZ and MW coordinated and completed the trial and collected all the data; SJG performed the laboratory analysis, compiled data and performed the statistical analysis; ZRG and SJG wrote the final draft and had primary responsibility for the final conduct. All authors read and approved the final manuscript.

\section{Acknowledgments}

The authors are indebted to the medical staff and all participants, in particular those who took the effort to supply this study with a blood sample.

\section{Sources of funding}

This study was funded by the grants from the Scientific Research Fund of National Ministry of Health, Republic of China (WKJ 2004-2-014) and the Priority Academic Program Development of Jiangsu Higher Education Institutions.

\section{Author details}

${ }^{1}$ Center for Disease Control of Changshu, Suzhou, 215500, Jiangsu, China. 2 Department of Epidemiology, School of Public Health, Soochow University, Suzhou, Jiangsu 215123, China. ${ }^{3}$ Health Bureau of Jiangsu Province, Nanjing, Jiangsu 21009, China. ${ }^{4}$ Center for Disease Control of Jiangsu Province, Nanjing, Jiangsu 210009, China.

Received: 11 September 2013 Accepted: 24 January 2014 Published: 26 January 2014

\section{References}

1. Lechleitner M: Obesity and the metabolic syndrome in the elderly - a mini-review. Gerontology 2008, 54(5):253-259.

2. Cullen P: Evidence that triglyceri des are an independent coronary heart disease risk factor. Am J Cardiol 2000, 86(9):943-949.

3. Berger J, Moller DE: The mechanisms of action of PPARs. Annu Rev Med 2002, 53:409-435

4. Azhar S: Peroxisome proliferator-activated receptors, metabolic syndrome and cardiovascular disease. Future Cardiol 2010, 6(5):657-683.

5. Schoonjans K, Staels B, Auwerx J: The peroxisome proliferator activated receptors (PPARs) and their effects on lipid metabolism and adipocytedifferentiation. Biochim Biophys Acta 1996, 1302(2):93-109.

6. Shah A, Rader DJ, Millar JS: The effect of PPAR-alpha agonism on apolipoprotein metabolism in humans. Atherosclerosis 2010, 210(1):35-40.

7. Fruchart JC: Peroxisome proliferator-activated receptor-alpha (PPARalpha): at the crossroads of obesity, diabetes and cardiovascular disease. Atherosclerosis 2009, 205(1):1-8.

8. Lacquemant C, Lepretre F, Pineda Torra I, Manraj M, Charpentier G, Ruiz J, Staels B, Froguel P: Mutation screening of the PPARalpha gene in type 2 diabetes associated with coronary heart disease. Diab Metab 2000, 26(5):393-401

9. Vohl MC, Lepage P, Gaudet D, Brewer CG, Bétard C, Perron P, Houde G, Cellier C, Faith JM, Després JP, Morgan K, Hudson TJ: Molecular scanning of the human PPARa gene: association of the rs 1800206 mutation with hyperapobetalipoproteinemia. J Lipid Res 2000, 41(6):945-952.

10. Yong EL, Li J, Liu MH: Single gene contributions: genetic variants of peroxisome proliferator-activated receptor (isoforms alpha, beta/delta and gamma ) and mechanisms of dyslipidemias. Curr Opin Lipidol 2008, 19(2):106-112
11. Mazzotti DR, Singulane CC, Ota VK, Rodrigues TP, Furuya TK, de Souza FJ, Cordeiro BG, Magalhães C, Chen ES, Jacomini A, Smith Mde A, Borsatto-Galera B: PPAR a polymorphisms as risk factors for dyslipidemia in a Brazilian population. Mol Genet Metab 2011, 102(2):189-193.

12. Chen ES, Mazzotti DR, Furuya TK, Cendoroglo MS, Ramos LR, Araujo LQ, Burbano RR, Smith Mde A: Association of PPARalpha gene polymorphisms and lipid serum levels in a Brazilian elderly population. Exp Mol Pathol 2011, 88(1):197-201.

13. Semple RK, Chatterjee VK, O'Rahilly S: PPAR gamma and human metabolic disease. J Clin Invest 2006, 116(3):581-589.

14. Yen CJ, Beamer BA, Negri C, Silver K, Brown KA, Yarnall DP, Burns DK, Roth J, Shuldiner AR, Silver K, Brown KA, Yarnall DP, Burns DK, Roth J, Shuldiner AR: Molecular scanning of the human peroxisome proliferator activated receptor gamma (hPPAR gamma) gene in diabetic Caucasians: identification of a Pro12Ala PPAR gamma 2 missense mutation. Biochem Biophys Res Commun 1997, 241(12):270-274.

15. Wu MH, Chu CH, Chou WY, Chou WY, Yang T, Hsu GC, Yu CP, Yu JC, Sun CA: Joint effect of peroxisome proliferator-activated receptor $\gamma$ genetic polymorphisms and estrogen-related risk factors on breast cancer risk: results from a case-control study in Taiwan. Breast Cancer Res Treat 2011, 127(3):777-784.

16. Clement $K$, Hercberg S, Passinge B, Galan P, Varroud-Vial M, Shuldiner AR, Beamer BA, Charpentier G, Guy-Grand B, Froguel P, Vaisse C: The Pro115GIn and Pro12Ala PPAR gamma gene mutations in obesity and type 2 diabetes. Int J Obes Relat Metab Disord 2000, 24(3):391-393.

17. Hara K, Okada T, Tobe K, Yasuda K, Mori Y, Kadowaki H, Hagura R, Akanuma $Y$, Kimura S, Ito C, Kadowaki T: The Pro12Ala polymorphism in PPAR gamma2 may confer resistance to type 2 diabetes. Biochem Biophys Res Commun 2000, 271(1):212-216.

18. Doney A, Fischer B, Frew D, Cumming A, Flavell DM, World M, Montgomery $H E$, Boyle D, Morris A, Palmer CN: Haplotype analysis of the PPAR gamma Pro12Ala and rs3856806 variants reveals opposing associations with body weight. BMC Genet 2002, 13(3):21.

19. Gu SJ, Liu MM, Guo ZR, Wu M, Chen Q Zhou ZY, Yu H, Zhang $L$, Luo WS: Gene-gene interactions among the peroxisome proliferator-activated receptor polymorphisms for. Gene 2013, 515(2):272-276.

20. Flavell DM, Pineda Torra I, Jamshidi Y, Evans D, Diamond JR, Elkeles RS, Bujac SR, Miller G, Talmud PJ, Staels B, Humphries SE: Variation in the PPAR alpha gene is associated with altered function in vitro and plasma lipid concentrations in Type II diabetic subjects. Diabetologia 2000, 43(5):673-680.

21. Shin MJ, Kanaya AM, Krauss RM: Polymorphisms in the peroxisome proliferator activated receptor a gene are associated with levels of apolipoprotein CIII and triglyceride in African-Americans but not Caucasians. Atherosclerosis 2008, 198(2):313-319.

22. Flavell DM, Jamshidi Y, Hawe E, Pineda Torra I, Taskinen MR, Frick MH, Nieminen MS, Kesäniemi YA, Pasternack A, Staels B, Miller G, Humphries SE, Talmud PJ, Syvänne M: Peroxisome proliferator-activated receptor alpha gene variants in fluence progression of coronary atherosclerosis and risk of coronary artery disease. Circulation 2002, 105(12):1440-1445.

23. Zak I, Balcerzyk A, Sarecka B, Niemiec P, Ciemniewski Z, Dylag S: Contemporaneous carriers tate of two or three "proatherosclerotic" variants of APOE, ICAM1, PPARA and PAI-1 genes differentiate CAD patients from healthy individuals. Clin Chim Acta 2005, 362(1-2):110-118

24. Iwata E, Matsuda H, Fukuda T, Fukuen S, Motomura T, Igarashi T, Yamamoto I, Azuma J: Mutations of the peroxisome proliferator-activated receptor $\gamma$ (PPARY) gene in a Japanese population: the Pro12Ala mutation in PPARY2 is associated with lower concentrations of serum total and non-HDL cholesterol. Diabetologia 2001, 44(10):1354-1355.

25. Pollex RL, Mamakeesick M, Zinman B, Harris SB, Hegele RA, Hanley AJ: Peroxisome proliferator-activated receptor $\gamma$ polymorphism Pro12Ala is associated with nephropathy in type 2 diabetes. $J$ Diabetes Complications 2007. 21(3):166-171.

26. Brand-Herrmann SM, Kuznetsova T, Wiechert A, Stolarz K, Tikhonoff $V$, Schmidt-Petersen K, Telgmann R, Casiglia E, Wang JG, Thijs L, Staessen JA, Brand $E$ : European project on genes in hypertension investigators: alcohol intake modulates the genetic association between hdl cholesterol and the ppary 2 pro12ala polymorphism. J Lipid Res 2005, 46(5):913-919.

27. Swarbrick MM, Chapman CM, McQuillan BM, Hung J, Thompson PL, Beilby JP: A Pro12Ala polymorphismin the human peroxisome proliferator-activated receptor- $\gamma 2$ is associated with combined hyperlipidaemia in obesity. Eur $J$ Endocrinol 2001, 144(3):277-282. 
28. Zhou X, Chen J, Xu W: Association between C1431T polymorphism in peroxisome proliferator-activated receptor- $\gamma$ gene and coronary artery disease in Chinese Han population. Mol Biol Rep 2012, 39(2):1863-1868.

29. Yilmaz-Aydogan H, Kurnaz O, Kurt O, Akadam-Teker B, Kucukhuseyin O, Tekeli A, Isbir T: Effects of the PPARG P12A and C161T gene variants on serum lipids in coronary heart disease patients with and without Type 2 diabetes. Mol Cell Biochem Dec 2011, 358(1-2):355-363.

30. Sapone A, Peters JM, Sakai S, Tomita S, Papiha SS, Dai R, Friedman FK, Gonzalez FJ: The human peroxisome proliferator-activated receptor alpha gene: identification and functional characterization of two natural allelic variants. Pharmacogenetics 2000, 10(4):321-333.

31. Deeb SS, Fajas L, Nemoto M, Pihlajamäki J, Mykkänen L, Kuusisto J, Laakso M, Fujimoto W, Auwerx J: A Pro12Ala substitution in PPARgamma2 associated with decreased receptor activity, lower body mass index and improved insulin sensitivity. Nat Genet 1998, 20(3):284-287.

32. Hu XS, Guo ZR, Zhou H, Shi ZM, Wu M, Zhang J, Sun GX, Zhou ZY, Pan XQ, Yao CL: Study on the prevalence of metabolic syndrome among 35-74 year-olds in Jiangsu province. Chin J Epidemiol 2006, 27(9):751-756.

33. Expert Panel on Detection: Expert panel on detection, evaluation, and treatment of high blood cholesterol in adults: executive summary of the third report of the national cholesterol education program - expert panel on detection, evaluation, and treatment of high blood cholesterol in adults (Adult Treatment Panel I II). Jama 2001, 285(19):2486-2497.

doi:10.1186/1476-511X-13-23

Cite this article as: Gu et al:: PPAR $a$ and PPAR $\gamma$ Polymorphisms as risk factors for Dyslipidemia in a Chinese han population. Lipids in Health and Disease 2014 13:23.

\section{Submit your next manuscript to BioMed Central and take full advantage of:}

- Convenient online submission

- Thorough peer review

- No space constraints or color figure charges

- Immediate publication on acceptance

- Inclusion in PubMed, CAS, Scopus and Google Scholar

- Research which is freely available for redistribution 